\title{
The Influence of Oxide on the Electrodeposition of Niobium from Alkali Fluoride Melts
}

\author{
Christensen, Erik; Wang, Xingdong; Barner, Jens H. Von; Østvold, T.; Bjerrum, Niels
}

Published in:

Journal of The Electrochemical Society

Link to article, DOI:

$10.1149 / 1.2054898$

Publication date:

1994

Document Version

Publisher's PDF, also known as Version of record

Link back to DTU Orbit

Citation (APA):

Christensen, E., Wang, X., Barner, J. H. V., Østvold, T., \& Bjerrum, N. (1994). The Influence of Oxide on the Electrodeposition of Niobium from Alkali Fluoride Melts. Journal of The Electrochemical Society, 141(5), 12121220. https://doi.org/10.1149/1.2054898

\section{General rights}

Copyright and moral rights for the publications made accessible in the public portal are retained by the authors and/or other copyright owners and it is a condition of accessing publications that users recognise and abide by the legal requirements associated with these rights.

- Users may download and print one copy of any publication from the public portal for the purpose of private study or research.

- You may not further distribute the material or use it for any profit-making activity or commercial gain

- You may freely distribute the URL identifying the publication in the public portal 


\section{Acknowledgment}

This manuscript is based on work supported by the $\mathrm{Na}$ tional Science Foundation under Grant No. CTS-8915745.

Manuscript submitted Sept. 29, 1993; revised manuscript received Feb. 1, 1994.

The University of New Hampshire assisted in meeting the publication costs of this article.

\section{REFERENCES}

1. E. Ben-Jacob and P. Garik, Nature, 343, 523 (1990) and references therein.

2. M. Matsushita, M. Sano, Y. Hayakawa, H. Honjo, and Y. Sawada, Phys. Rev. Lett., 53, 286 (1984).

3. Y. Sawada, A. Dougherty, and J. P. Gollub, ibid., 56, 1260 (1986).

4. D. Grier, E. Ben-Jacob, R. Clarke, and L. M. Sander, ibid., 56, 1264 (1986).

5. E. Ben-Jacob, G. Deutscher, P. Garik, N. D. Goldenfeld, and Y. Lareah, ibid., 57, 1903 (1986).

6. D. Grier, D. A. Kessler, and L. M. Sander, ibid, 59, 2315 (1987).

7. P. Garik, D. Barkey, E. Ben-Jacob, E. Bochner, N. Broxholm, B. Miller, B. Orr, and R. Zamir, Phys. Rev. Lett. 62, 2702 (1989).

8. G. L. M. K. S. Kahanda and M. Tomkiewicz, This Journal, 136, 1497 (1989).

9. D. B. Hibbert and J. R. Melrose, Proc. Roy. Soc. London, Ser. A, 423, 149 (1989).

10. D. P. Barkey and P. D. Laporte, This Journal, 137, 1655 (1990).

11. F. Sagues, F. Mas, M. Vilarrasa, and J. M. Costa, J. Electroanal. Chem., 278, 351 (1990).

12. J. R. Melrose, D. B. Hibbert, and R. C. Ball, Phys. Rev. Lett., 65, 3009 (1990).

13. V. Fluery, J. Chazaviel, M. Rosso, and B. Sopoval, J. Electroanal. Chem., 290, 249 (1990).

14. C. P. Chen and J. Jorne, This Journal, 137, 2047 (1990).

15. P. P. Trigueros, J. Claret, F. Mas, and F. Sagues, J. Elec- troanal. Chem., 312, 219 (1991).

16. P. P. Trigueros, J. Claret, F. Mas, and F. Sagues, ibid., In press (1994).

17. D. Barkey, This Journal, 138, 2912 (1991).

18. P. Garik, J. Hetrick, B. Orr, D. Barkey, and E. Ben-Jacob, Phys. Rev. Lett., 66, 1606 (1991).

19. V. Fluery, J. N. Chazaviel, and M. Rosso, ibid., 67, 2492 (1992).

20. M. Rosso, J. N. Chazalviel, V. Fleury, and E. Chassaing, Electrochim. Acta, 39, 507 (1994).

21. Y. Awakura and Y. Kondo, This Journal, 123, 1184 (1976).

22. Y. Fukunaka, T. Minegishi, N. Nishioka, and Y. Kondo, ibid., 128, 1274 (1981).

23. Y. Fukunaka, T. Yamamoto, and Y. Kondo, ibid., 136, 3630 (1989).

24. R. N. O'Brien, W. F. Yakmyshyn, and J. Leja, ibid., 110, 820 (1974).

25. R. N. O'Brien and K. S. VC. Santhanam, ibid., 130, 1114 (1983).

26. R. N. O'Brien and P. M. Saville, ibid., 137, 3797 (1990).

27. F. R. McLarnon, R. H. Muller, and C. W. Tobias, ibid., 122, 59 (1975)

28. F. R. McLarnon, R. H. Muller, and C. W. Tobias, Ind. Eng. Chem. Fundam., 18, 97 (1979).

29. F. R. McLarnon, R. H. Muller, and C. W. Tobias, This Journal, 129, 2201 (1982).

30. A. Tvarusko and L. S. Watkins, ibid., 118, 580 (1971).

31. D. W. Watt and C. M. Vest, Exp. Fluids, 5, 401 (1987).

32. D. W. Watt and C. M. Vest, ibid., 8, 301 (1990).

33. C. M. Vest, Holographic Interferometry, John Wiley \& Sons, Inc., New York (1979).

34. A. J. Bard and L. R. Faulkner, Electrochemical Methods, John Wiley \& Sons, Inc., New York (1980).

35. D. G. Miller, J. A. Rard, L. B. Eppstein, and R. A. Robinson, J. Soln. Chem., 9, 467 (1980).

36. V. G. Levich, Physicochemical Hydrodynamics, Prentice Hall, Englewood Cliffs, NJ (1962).

37. R. Bruinsma and S. Alexander, J. Chem. Phys., 92, 3074 (1990).

\title{
The Influence of Oxide on the Electrodeposition of Niobium from Alkali Fluoride Melts
}

\author{
E. Christensen, ${ }^{a}$ Xindong Wang, ${ }^{a}$ J. H. von Barner, ${ }^{b}$ T. Østfold, ${ }^{c}$ and N. J. Bjerrum,a \\ ${ }^{a}$ Materials Science Group, Chemistry Department $A$, and ${ }^{b}$ Institute of Mineral Industry, \\ The Technical University of Denmark, DK-2800 Lyngby, Denmark \\ ${ }^{\mathrm{c}}$ Institute of Inorganic Chemistry, The University of Trondheim, The Norwegian Institute of Technology, \\ N-7034 Trondheim, Norway
}

\begin{abstract}
Electrodeposit of niobium metal from $\mathrm{K}_{2} \mathrm{NbF}_{7}-\mathrm{LiF}-\mathrm{NaF}-\mathrm{KF}-\mathrm{Na}_{2} \mathrm{O}$ melts at $700^{\circ} \mathrm{C}$ has been investigated. It was found that the equilibrium oxidation state of niobium was four for initial $\mathrm{O}^{2-} / \mathrm{Nb}(\mathrm{V})$ ratios of up to at least one. On the other hand when a niobium metal sheet was used for the reduction, average oxidation states close to five were obtained. Cyclic voltammetry showed that $\mathrm{NbF}_{7}^{2-}$ is reduced in two steps. A mechanism $\mathrm{Nb}(\mathrm{V}) \rightarrow \mathrm{Nb}(\mathrm{IV}) \rightarrow \mathrm{Nb}(0)$ is proposed. When oxide is present, new waves due to reduction of niobium mono-oxofluoro and dioxofluoro complexes are observed at -0.6 and $-0.74 \mathrm{~V}$, respectively. In addition plating experiments were also performed. The substrates in our work were low-carbon steel, the anodes niobium metal, and the current density was around $90 \mathrm{~mA} / \mathrm{cm}^{2}$. It was found that the presence of at least 1 mole percent of oxide was necessary to obtain current efficiencies higher than $30 \%$. The highest current efficiencies obtained were around $95 \%$. For oxide/ $\mathrm{Nb}(\mathrm{V})$ molar ratios equal to or higher than one, partially nonmetallic surface layers were deposited.
\end{abstract}

Senderoff and Mellors ${ }^{1-5}$ were the first to demonstrate that it was possible to produce coherent coatings of niobium and other refractory metals by electroplating from molten fluoride solvents. Since then the reduction mechanism of $\mathrm{Nb}(\mathrm{V})$ in fluoride and mixed fluoride-chloride melts has been the subject of several investigations. ${ }^{6-15}$ However, there seems to be quite a disagreement concerning the conclusions on the reduction path proposed in the different articles.

* Electrochemical Society Life Member.
Essentially three types of models have been put forward to explain the electrochemical data. ${ }^{3,6,15}$ These include, besides $\mathrm{Nb}(\mathrm{V})$ and niobium metal, reduced species in the oxidation states $+\mathrm{IV},+\mathrm{III},+\mathrm{II}$, and $+\mathrm{I}$.

Senderoff and Mellors ${ }^{3}$ claim a three-step reduction process for $\mathrm{Nb}(\mathrm{V})$ in the eutectic LiF-NaF-KF-melt (also called FLINAK)

$$
\begin{aligned}
& \mathrm{Nb}^{5+}+e^{-} \rightarrow \mathrm{Nb}^{4+} \\
& \mathrm{Nb}^{4+}+3 e^{-} \rightarrow \mathrm{Nb}^{+}
\end{aligned}
$$




$$
\mathrm{Nb}^{+}+e^{-} \rightarrow \mathrm{Nb}^{0}
$$

In $\mathrm{LiF}-\mathrm{NaF}$ melts Zhiyu and Taxil ${ }^{11}$ report $\mathrm{Nb}(\mathrm{V})$ to reduce in two steps

$$
\begin{aligned}
& \mathrm{Nb}^{5+}+\dot{e}^{-} \rightarrow \mathrm{Nb}^{4+} \\
& \mathrm{Nb}^{4+}+4 e^{-} \rightarrow \mathrm{Nb}^{0}
\end{aligned}
$$

For LiF-KF melts Los and Josiak ${ }^{b}$ suggested another twostep process

$$
\begin{aligned}
& \mathrm{Nb}^{5+}+2 e^{-} \rightarrow \mathrm{Nb}^{3+} \\
& \mathrm{Nb}^{3+}+3 e^{-} \rightarrow \mathrm{Nb}^{0}
\end{aligned}
$$

Chronopotentiometric measurements carried out by Los and Josiak, ${ }^{6}$ however, indicate the presence of an $\mathrm{Nb}^{2+}$ species, and consequently a more complicated reduction path than stated in Eq. 6 and 7.

In chloride-fluoride melts Chemla and Grinevitch ${ }^{9}$ and others $^{13,14}$ for $\mathrm{KCl}-\mathrm{NaCl}-\mathrm{K}_{2} \mathrm{NbF}_{7}$ melts, and Konstantinov et al. ${ }^{10}$ for $\mathrm{KCl}-\mathrm{KF}-\mathrm{K}_{2} \mathrm{NbF}_{7}$ melts report the same two-step process as given by Zhiyu and Taxil ${ }^{11}$ i.e., as Eq. 4 , 5. In contrast to this, Sakawa and $\mathrm{Kuroda}^{12}$ for $\mathrm{KCl}-\mathrm{NaCl}-$ $\mathrm{K}_{2} \mathrm{NbF}_{7}$ melts have reported the two-step process as in Eq. 6,7 .

The situation changes from these just described investigations when the melt is in contact with niobium metal. This is generally the case when a plating process is carried out, because a niobium anode is usually used. In this case niobium(V) added to the melt will be chemically reduced, so that valence states lower than five will be present initially. Until now only a few papers ${ }^{3,13,15}$ have focused on this subject. The overall mechanism also depends on the species formed by the anode process. Nagakawa and Hirobayashi ${ }^{15}$ found for $\mathrm{LiF}-\mathrm{NaF}-\mathrm{KF}$ melts as well as mixed chloridefluoride melts, that when niobium was introduced in the melt entirely by anodic dissolution, it was present as a mixture of $\mathrm{Nb}$ (II) and $\mathrm{Nb}$ (III). On the other hand Khalidi et al. ${ }^{13}$ found for mixed chloride-fluoride melts that niobium was dissolved as $\mathrm{Nb}(\mathrm{IV})$ for current densities of $100 \mathrm{~mA} / \mathrm{cm}^{2}$ or higher. When the current density was smaller species with oxidation states lower than four were also formed.

The mechanism of the process may be changed by the presence of oxide impurities. Oxide containing molten fluoride solutions of $\mathrm{Nb}^{5+}$ have been studied by infrared reflection spectroscopy ${ }^{16}$ as well as by Raman spectroscopy. ${ }^{17}$ These experiments showed that $\mathrm{Nb}^{5+}$, originally present as $\mathrm{NbF}_{7}^{2-}$ complexes, easily reacted with oxide to form oxofluoride complexes such as $\mathrm{NbOF}_{5}^{2-}$ and $\mathrm{NbO}_{2} \mathrm{~F}_{4}^{3-}$ when consecutive amounts of oxide were added.

As shown by Konstantinov et al. ${ }^{10}$ the formation of oxofluoride complexes changes the reduction mechanism of $\mathrm{Nb}^{5+}$ completely. Their results indicate a one-step discharge of the niobium(V) mono-oxofluoro complex possibly to another oxide containing compound. The discharge of the suggested $\mathrm{NbO}_{2} \mathrm{~F}_{4}^{3-}$ complex was found to be a three-step process. ${ }^{10}$ Chemla and Grinevitch ${ }^{9}$ also observed a change from a two-step to a one-step process when $\mathrm{K}_{2} \mathrm{NbOF}_{5}$ was added to a KCl-NaCl melt. In this case NbO was deposited at the electrode. At the $X_{0} / X_{\mathrm{Nb}}$ ratio equal to one, both Chemla and Grinevitch ${ }^{9}$ and Konstantinov et al. ${ }^{10}$ observed the single reduction step at a less reducing potential than the metal producing reduction step for pure $\mathrm{K}_{2} \mathrm{NbF}_{7}$.

These observations indicate how important the oxide content in the melt may be during electrochemical studies of the reduction of niobium species. Normally melts with low $\mathrm{Nb}^{5+}$ concentrations (less than $0.1 \mathrm{~m} / \mathrm{o}$ ) are studied thus making it very important to keep the oxide content of the solvent very low in order to have an oxide to niobium ratio of much less than one.

The present work deals with the niobium plating process from FLINAK melts focusing on the role of oxide present in the molten salt bath.

\section{Experimental}

Chemicals and materials.- $\mathrm{K}_{2} \mathrm{NbF}_{7}$ from ALFA Chemicals was used without further purification but was always checked by chemical analysis. Typical results were Nb:
$30 \pm 1, \mathrm{~K}: 26.8 \pm 0.3$, and $\mathrm{F}: 42.9 \pm 0.8$ weight percent (w/o) compared with calculated values $\mathrm{Nb}: 30.6, \mathrm{~K}: 25.7$, and $\mathrm{F}$ : 43.7 w/o. Alternatively $\mathrm{K}_{2} \mathrm{NbF}_{7}$ was prepared as follows: hot solutions of $\mathrm{Nb}_{2} \mathrm{O}_{5}\left(13.6 \mathrm{~g} \mathrm{Nb}_{2} \mathrm{O}_{5}\right.$ from CERAC of $99.95 \%$ purity in $100 \mathrm{ml} 15 \mathrm{w} / \mathrm{o} \mathrm{HF}$ solution) and $\mathrm{KF}$ (18.2 g $\mathrm{KF}$ Merck, analytical grade in $100 \mathrm{ml} 15 \mathrm{w} / \mathrm{o} \mathrm{HF}$ solution) were mixed. A white precipitate was formed when this mixture was allowed to cool. This precipitate was recrystallized in $40 \mathrm{w} / \mathrm{o}$ hydrofluoric acid as proposed by Sakawa and Kuroda. ${ }^{18}$ Finally the product was washed with ethanol $(99.9 \%)$ and ether. Analysis of this product gave the same results as the best material from ALFA Chemicals.

The analytical grade alkali fluorides from Merck were purified by slow recrystallization from the molten state, keeping a cooling rate of $3^{\circ} \mathrm{C} / \mathrm{h}$.

The oxide content of the pure FLINAK melts was estimated from voltammograms obtained from these melts, as outlined later in this paper.

$\mathrm{Na}_{2} \mathrm{O}$ was obtained from Aldrich (98\%) and was used without further purification. Alternatively, $\mathrm{Na}_{2} \mathrm{O}$ was prepared by heating analytical grade $\mathrm{Na}_{2} \mathrm{O}_{2}$ from Merck in an alumina crucible under vacuum at $600^{\circ} \mathrm{C}$ for $12 \mathrm{~h} .{ }^{19}$ Analysis by titration with hydrochloric acid gave typically $98 \mathrm{w} / \mathrm{o}$ in both cases.

Rods of low carbon steel (diameter $5 \mathrm{~mm}$ ) were used as substrates for the plating experiments. Before use they were anodically cleaned in a basic solution, and then treated with an acid fluoride solution to remove oxide from the surface. In some cases the iron content of the melts (after plating) was determined by atomic absorption. In this case the melt samples were dissolved by boiling $40 \mathrm{w} / \mathrm{o}$ hydrofluoric acid in a Teflon beaker. Niobium metal foil $(1 \mathrm{~mm})$ for the anodes was obtained from Goodfellow $(99.9 \%)$. Before use the anodes were treated with concentrated hydrofluoric acid $(40 \%)$ to remove the oxide layer.

The glassy carbon crucibles used as containers for the melts for all experiments were from Cabone-Lorraine (V25).

The holders for the electrochemical cells for plating experiments (Fig. 2) and for voltammetry were constructed of acid resistant stainless steel containing $2 \%$ molybdenum. The electroplated metal deposits were investigated using a Philips SEM 505 scanning electron microscope equipped with an energy dispersive analysis by $\mathrm{x}$-ray (EDAX). The $x$-ray diffraction analyses were carried out using a Philips PW 1050/25 diffractometer with continuous divergence slit or a Gandolfi camera. In all cases $\mathrm{Cu}_{\mathrm{K \alpha} \alpha}$ radiation was applied.

Procedures.--The experimental setup used for the plating experiments is shown in Fig. 1. The same equipment was also used for experiments where chemical reduction of niobium(V) was performed by adding niobium metal in excess or by adding the niobium containing alloy described below. Before each run the furnace chamber was kept under a flow of argon for $1 \mathrm{~h}$ at room temperature. Then heating to the experimental temperature of $700^{\circ} \mathrm{C}$ was initiated. When this temperature was reached, a change to overpressure $\left(P_{\text {total }}=120 \mathrm{kPa}\right)$ [using the automatic pressure regulating system (Fig. 1)] was carried out. The furnace was a standard Kanthal wound type. Details of the electrolysis cell are shown in Fig. 2. All melts were premixed by heating to $700^{\circ} \mathrm{C}$ for $4 \mathrm{~h}$ before the crucible was raised until the electrodes were dipping into the melt. After $3 \mathrm{~h}$, electrolysis was initiated. In this way, the chemical reaction between $\mathrm{Nb}(\mathrm{V})$ in the melt and the niobium metal anode was allowed to take place before the electrochemical reduction of niobium in the melt was started. No agitating of the melt was performed. In all cases, the time of electrolysis was $3 \mathrm{~h}$, and the cathodic current density was $94 \pm 18 \mathrm{~mA} / \mathrm{cm}^{2}$. The area of the electrodes in contact with the melt were $2.5 \pm$ $0.5 \mathrm{~cm}^{2}$ for the cathode, and $11.5 \mathrm{~cm}^{2}$ for the anode (one side only). The variation in cathode area is due to differences in the height of the melts in the crucibles. The amount of melt used for each experiment was in the range of $22 \mathrm{~g}$ (depending on the composition). 
To investigate the chemical reaction between $\mathrm{Nb}(\mathrm{V})$ and niobium metal, several types of experimental procedures were applied. Sheets of niobium metal (area approximately $4 \mathrm{~cm}^{2}$ ) were used for reduction experiments with varying $\mathrm{Na}_{2} \mathrm{O}$ content. In these experiments, the niobium metal (treated in concentrated hydrofluoric acid to remove oxide on the surface) was placed in the crucible together with the chemicals at room temperature and then heated to $700^{\circ} \mathrm{C}$ for 10 to $66 \mathrm{~h}$. After cooling, the solidified melts were treated with a saturated boric acid solution until the niobium metal plates could be removed and cleaned. The number of grams of niobium metal dissolved was determined from the weight loss, and the average oxidation state of niobium could be calculated.

An alternative procedure was applied, especially to determine the necessary equilibration time before the plating experiments. The niobium metal cylinders used as anodes (area $23 \mathrm{~cm}^{2}$ ) in the plating experiments (Fig. 2) were dipped into the premixed melt for different periods of time. When this period was over, the crucible was lowered, i.e., the sheets were taken out of the melt, and the furnace cooled to room temperature.

From these experiments it appeared, as discussed below, that some serious experimental errors were present when using niobium metal sheets for the reduction. Consequently, a third procedure for these chemical reduction experiments was applied. Instead of niobium metal sheets, an alloy of gold (47.4 w/o), bismuth ( $47.5 \mathrm{w} / \mathrm{o})$, and niobium $(5.0 \mathrm{w} / \mathrm{o})$ was used. At $700^{\circ} \mathrm{C}$ this alloy is a liquid saturated with solid niobium metal. After cooling to room temperature the solidified alloy could be removed from the melt after treatment with a hot boric acid solution. The metal alloy was then weighed, and its weight loss assumed to represent the amount of niobium dissolved from it. In this way the problems appearing when niobium metal sheets were used (formation of a protective oxide layer, mechanical disintegration), were minimized. However, a very long equilibration time $(200 \mathrm{~h}$ ) was found to be necessary. This is probably because the activity of niobium metal on the surface of the alloy is low.

During the equilibration time the furnace system was rocked by an electrical motor, causing agitation. In this way the metal surface was kept fresh to obtain a higher reaction rate. Also, a reaction between the alloy and the glassy carbon crucible, which was observed in some preliminary experiments, was minimized. (In certain cases the

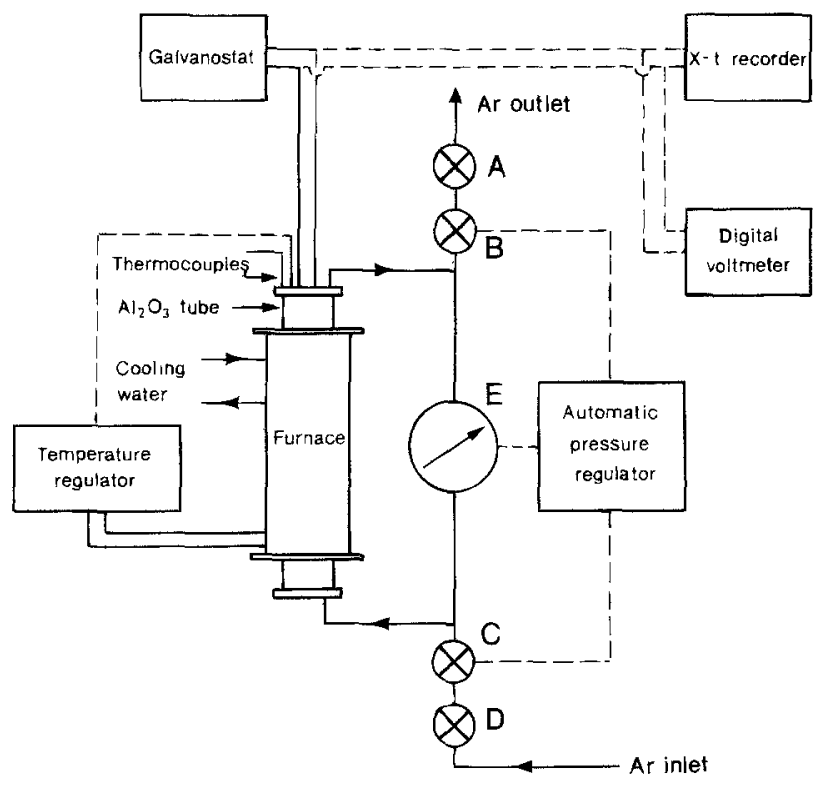

Fig. 1. Experimental setup for plating experiments: $A, D$, manually controlled valves; B, C, magnetic valves controlled by the automatic pressure regulator; $\mathrm{E}$, manometer, which is controlling the automatic pressure regulator.

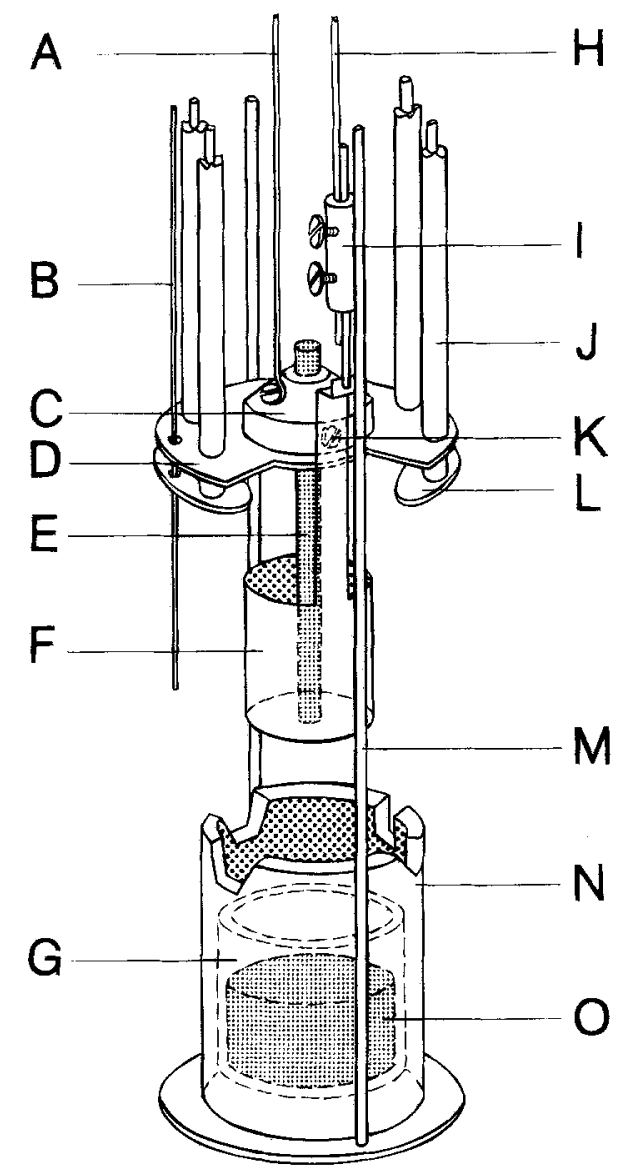

Fig. 2. Details of the electrochemical cell: $A$, cathode wire in stainless steel; B, thermocouple; C, adapter for iron cathode; D, base for the adapter $C$ in stainless steel, electrically insulated; $E$, iron cathode; F, niobium anode; $G$, glassy carbon crucible; $H$, anode wire in stainless steel; I, connection link between anode and anode wire; J, tubes of alumina ceramics which provide electrical insulation; $K$, screw used for mounting and dismounting iron cathodes; $L$, bottom plate; $M$, stainless steel rods which can be moved to raise or lower the crucible with the melt; $N$, alumina crucible; $O$, fluoride melt.

solidified metal alloy was impossible to remove from the glassy carbon surface without breaking the crucible).

That the metal alloy was a liquid saturated with niobium metal at $700^{\circ} \mathrm{C}$ could be seen by examining it after an experiment. By cutting the rather brittle material, it could be seen that some niobium had not been completely dissolved in the alloy. The quantities used were such that if all the $\mathrm{Nb}(\mathrm{V})$ in the melt was completely reduced to $\mathrm{Nb}(\mathrm{IV})$ only half of the niobium metal initially present was dissolved.

An experiment in which no niobium metal was added to the alloy was performed, in order to check the stability of the gold-bismuth mixture. It was found that a certain weight loss took place, corresponding to oxidation of either gold or bismuth by $\mathrm{Nb}(\mathrm{V})$ in the melt. On the other hand, as soon as the less noble niobium metal is present in the alloy, this component will be the first to react. If niobium metal is present in excess, reaction with gold or bismuth should therefore not be a problem. This assumption is supported by the fact that the average oxidation state of the reduced niobium is close to an integer (i.e., 4).

The metal alloys were initially prepared as follows: the necessary amounts of the metals together with some $\mathrm{KCl}$ (purified by $\mathrm{HCl}$ treatment and with $3.0 \mathrm{~g}$ of $\mathrm{KCl}$ to $7.2 \mathrm{~g}$ of metals) were placed in an ampul of fused quartz, which was then sealed under $0.2 \mathrm{~atm}$ of argon. The mixture was thenmelted with a Bunsen burner until the metals had united in a single lump. After this, the ampul was heated in a furnace to $850^{\circ} \mathrm{C}$ for $2 \mathrm{~h}$. After cooling $\mathrm{KCl}$ could be dissolved in water, and the metal alloy was ready for use. 


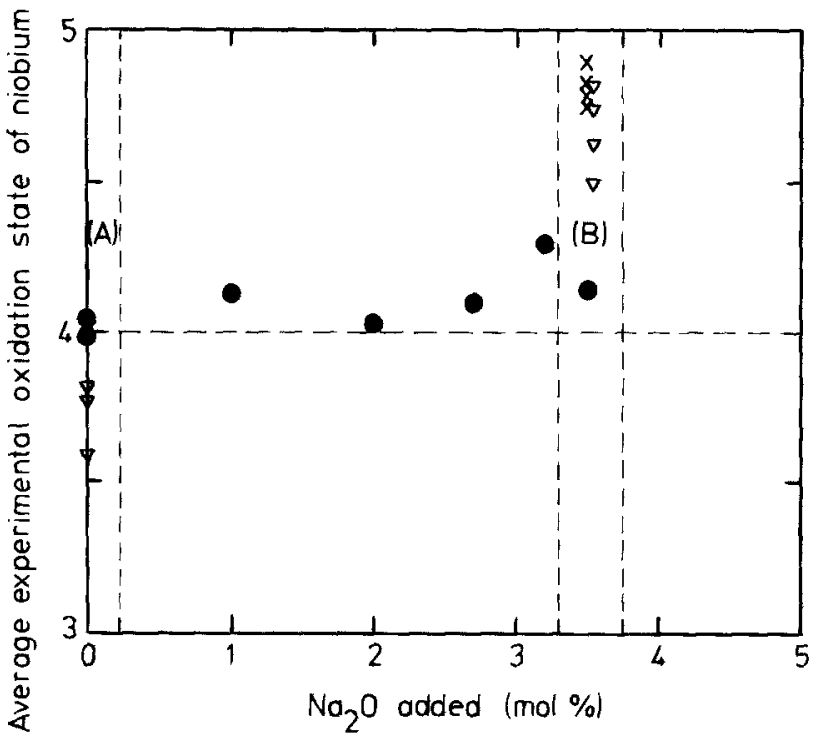

Fig. 3. Average experimental oxidation state of niobium after reaction at $700^{\circ} \mathrm{C}$ between $\mathrm{Nb}(\mathrm{V})$ and niobium metal. The initial niobium content was in all cases $2.7 \mathrm{~m} / \mathrm{o}$. (O) Obtained by the use of a $\mathrm{Au}-\mathrm{Bi}-\mathrm{Nb}$ alloy for reduction. Reaction time under agitation $200 \mathrm{~h}$. ( $\nabla)$ Obtained by use of niobium sheet for $10 \mathrm{~h} .(\times)$ Obtained by use of niobium sheet for 30 to $66 \mathrm{~h}$. Approximately $22.5 \mathrm{~g}$ of melt were used for each experiment.

All voltammetric experiments were carried out in a furnace under argon atmosphere $(99.99 \%)$ at $700 \pm 0.5^{\circ} \mathrm{C}$. The furnace was equipped with a nickel tube and with watercooled end covers. The pressure of argon was kept at $120 \mathrm{kPa}$ by an automatic controller. Before each experiment, the furnace chamber was evacuated to a pressure of about $3 \mathrm{~Pa}$ and heated to $200^{\circ} \mathrm{C}$ before the argon atmosphere was established. A system with three electrodes, i.e., a reference electrode, a working electrode, and a counterelectrode was used for the cyclic voltammetry study. In the first set of experiments a platinum wire was taken as a quasi-reference electrode. To obtain a fixed reference we later applied a $\mathrm{Ni} / \mathrm{NiF}_{2}$ electrode of the type first reported by Jenkins et al. ${ }^{20}$ Here the $\mathrm{Ni} / \mathrm{NiF}_{2}$-FLINAK system is kept inside a boron nitride tube. The counterelectrode was a foil of platinum (about $4 \mathrm{~cm}^{2}$ ). The working electrode was made of $0.5 \mathrm{~mm}$ diam platinum wire. The vertical position

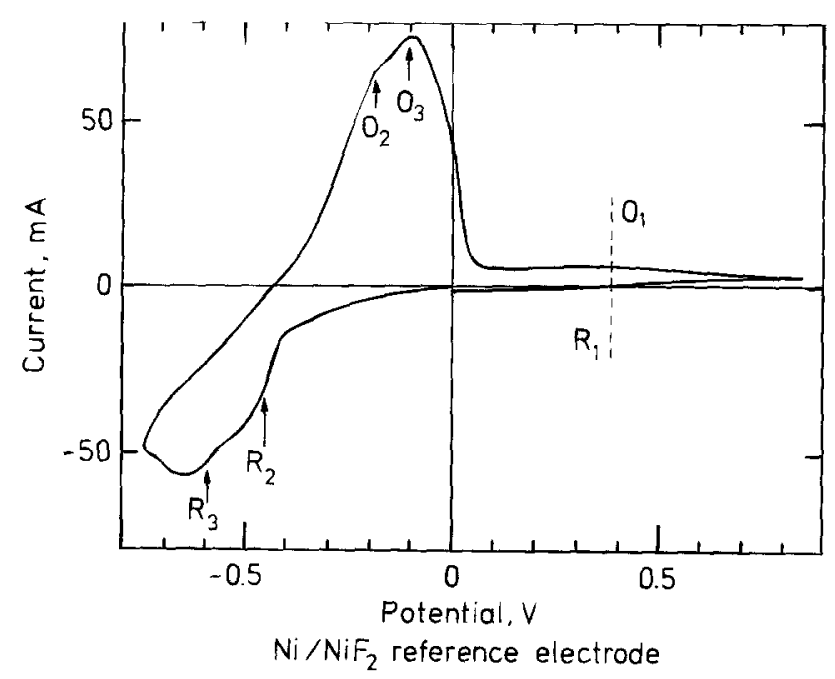

Fig. 4. Voltammograms at $700^{\circ} \mathrm{C}$ of $0.90 \mathrm{~m} / 0 \mathrm{~K}_{2} \mathrm{NbF}_{7}$ in FLINAK with $0.35 \mathrm{~m} / 0 \mathrm{Na}_{2} \mathrm{O}$ added, obtained with a $\mathrm{Pt}$ working electrode $(0.5 \mathrm{~mm}$ diam, immersed in approximately $1 \mathrm{~mm}$ in the melt), $\mathrm{Pr}$ counterelectrode, and $\mathrm{Ni} / \mathrm{NiF}_{2}$ reference electrode. Scan rate $0.2 \mathrm{~V} \mathrm{~s}^{-1}$.

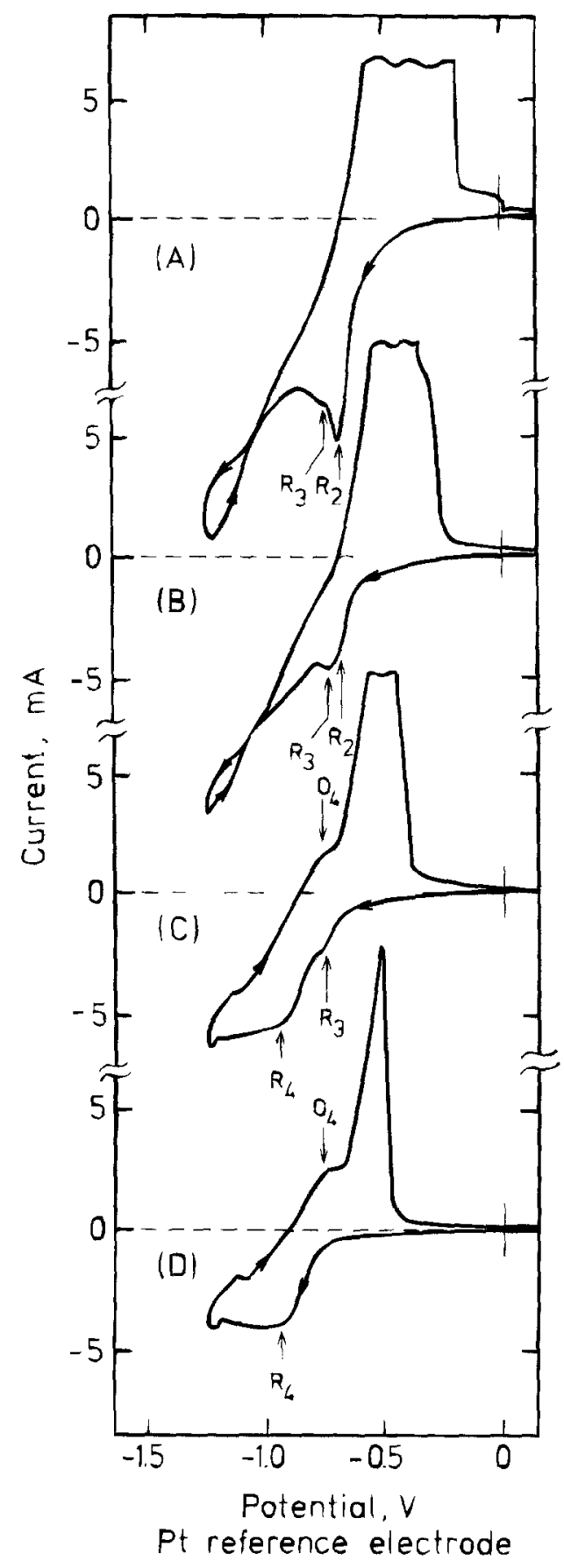

Fig. 5. Voltammograms of $0.25 \mathrm{~m} / \mathrm{o} \mathrm{K} \mathrm{NbF}_{7}$ dissolved in FLINAK at $700^{\circ} \mathrm{C}$ vs. $\mathrm{Na}_{2} \mathrm{O}$ additions. Scan rate $0.4 \mathrm{~V} \mathrm{~s}^{-1}$. Pf working electrode $10.5 \mathrm{~mm}$ diam, $2 \mathrm{~mm}$ immersed in the melt), Pt counterelectrode, and Pt reference electrode. Oxide added (m/o): A, 0; B, 0.03; C, $0.10 ; D, 0.15$.

of the working electrode could be controlled by a screw micrometer to obtain the desired electrode surface area. Voltammograms were obtained by means of a galvanostat/ potentiostat built at the Technical University of Denmark, or by a Solartron 1286 electrochemical interphase with computer control.

\section{Results and Discussion}

Oxidation state of niobium as a function of oxide content in FLINAK- $\mathrm{K}_{2} \mathrm{NbF}_{7}$ melts.-In Fig. 3 the results of the chemical reduction experiments with a FLINAK melt containing $2.7 \mathrm{~m} / \mathrm{o} \mathrm{K} \mathrm{NbF}_{7}$ at $700^{\circ} \mathrm{C}$ are shown. To illustrate the difficulties in using only sheets of pure niobium to reduce $\mathrm{Nb}(\mathrm{V})$ examples of results obtained in this way are given in range (A) and (B) in Fig. 3. As can be seen, the scattering of results is large in both ranges. At low oxide 
Table I. Reduction potentials of niobium species observed in FLINAK melts (vs. $\left.\mathrm{Ni} / \mathrm{Ni}^{2+}\right)$.

\begin{tabular}{cr}
$\begin{array}{c}\text { Potential } \\
(\mathrm{V})\end{array}$ & Ref. \\
\hline$-0.11,-0.76,-1.02$ & 3 \\
$-0.2,-0.7,-1.2$ & 15 \\
$-(0.81$ to 0.84$),-(0.95$ to 1.18$)$ & 6
\end{tabular}

(nuoride complexes:

$+0.38,-0.47$

This work.

Oxofluoride complexes:

$-0.6,-0.74$

This work

contents, i.e., range (A), values of oxidation state lower than four were obtained. However, it was observed that the niobium metal had a tendency to disintegrate because of mechanical tensions. We did not succeed in solving this problem by annealing the metal sheets before use. Because of this, the weight losses determined could be too high.

At high oxide contents, i.e., range (B), values of oxidation state between four and five were obtained. In these cases the surface of the metal sheets were covered by a gray coating, which, as follows from the results described below, apparently was a protective oxide layer. Because of this the reaction was prevented from reaching equilibrium, and the weight losses which were determined were too low. As is seen in the figure, even a very long reaction time could not make the reaction proceed any further when first stopped. Furthermore, there is no clear systematic dependence of the oxidation state obtained, i.e., the weight loss and the reaction time.

In contrast to these results, the experiments using the liquid gold-bismuth-niobium alloy at $700^{\circ} \mathrm{C}$, all gave oxidation states close to four. It can be seen that the addition of oxide up to $3.5 \mathrm{~m} / \mathrm{o}$ does not affect the average oxidation state significantly. This means that niobium is present as $\mathrm{Nb}(\mathrm{IV}) \mathrm{F}_{x}$ and possibly as $\mathrm{Nb}$ (IV) $\mathrm{OF}_{y}$ units [with charge $-(4-x)$ and $-(4-y)$, respectively]. $\mathrm{Nb}$ (IV) is probably not as strong an oxide getter as $\mathrm{Nb}(\mathrm{V})$, and the equilibrium

$$
\mathrm{Nb}(\mathrm{IV}) \mathrm{F}_{x}+\mathrm{O}^{2-} \leftrightarrow \mathrm{Nb}(\mathrm{IV}) \mathrm{OF}_{y}
$$

may not be completely shifted to the right. On the basis of the present experiments, in principle it cannot be stated

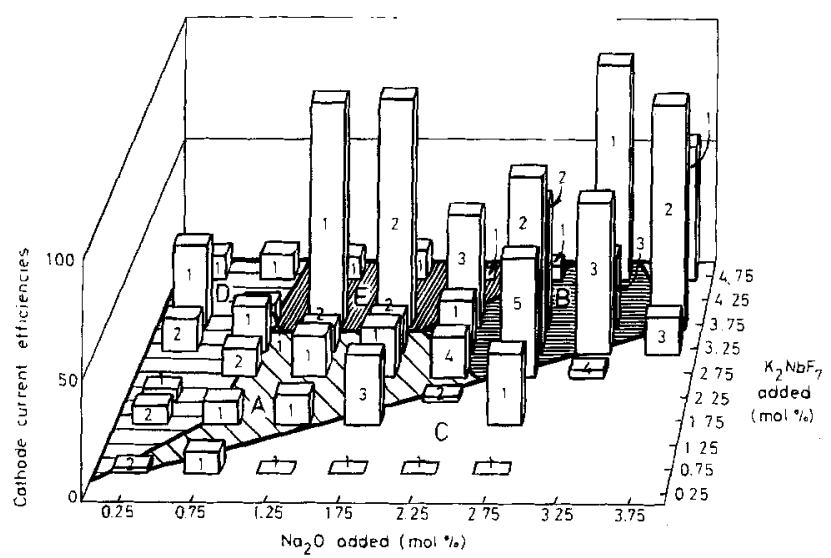

Fig. 6. Current efficiency for niobium plating in FLINAK as a function of melt composition. Each "building" has the height of the average value of the current efficiencies obtained using melts of compositions within the corresponding squares. The current efficiencies are calculated on the basis of a four-electron process. The current density was $94 \pm 18 \mathrm{~mA} / \mathrm{cm}^{2}$ and the temperature was $700^{\circ} \mathrm{C}$ in all cases. The areas marked $A, B, C, D$ and $E$ refer to the different types of deposits and melts discussed in the text. The color of the solidified melts were as follows; A, light yellowish green; B, green, C, green; D, purple; E, purple. For deposits see the following figures: $A$ and $B$ as Fig. $7 a$ and b; C, Fig. 7c; D, Fig. 8a and b; E, Fig. $8 c$ and $d$.
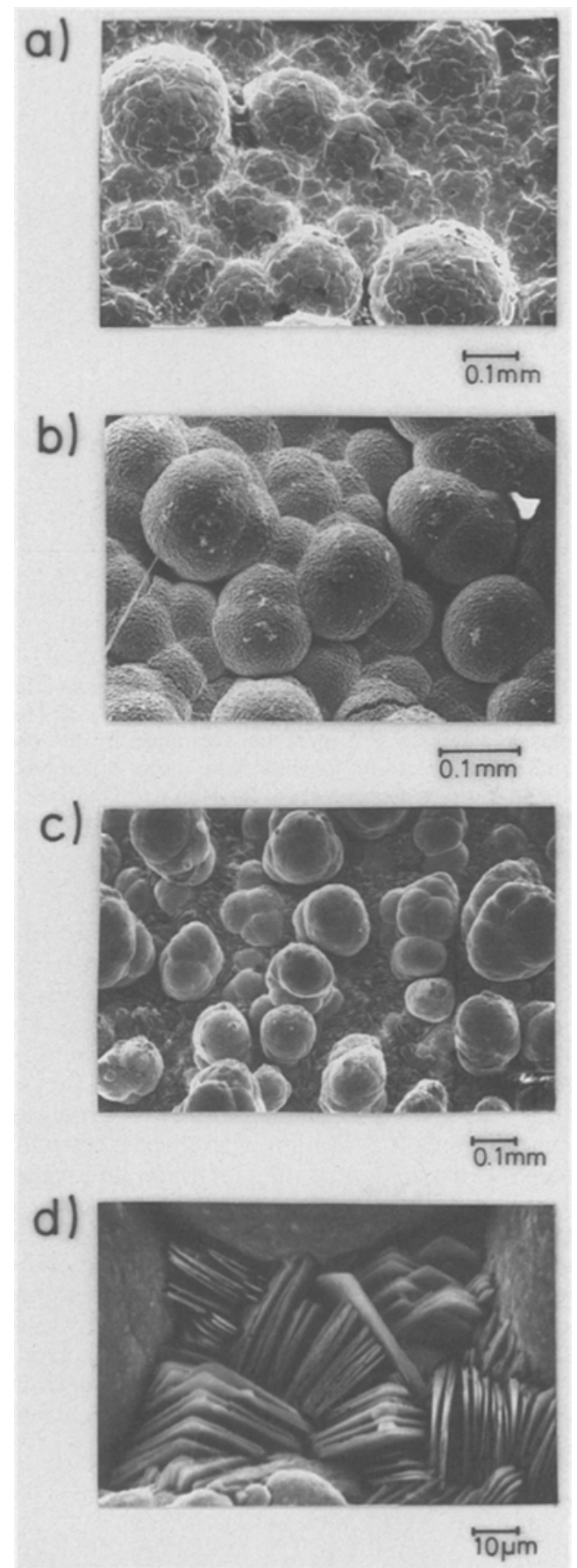

Fig. 7. SEM micrographs of surfaces of niobium deposits from different melt compositions. (a) Good quality niobium deposit. The melt used for the electrolysis contained $3.75 \mathrm{~m} / \mathrm{o}$ of niobium and $3.2 \mathrm{~m} / \mathrm{o}$ of oxide. The current efficiency in the experiment was $69 \%$, and EDX analysis gave $100 \% \mathrm{Nb}$. (b) Deposit with "ball-like structures" appearing very clearly. Melf composition $3.2 \mathrm{~m} / \mathrm{o}$ of niobium and $3.52 \mathrm{~m} / \mathrm{o}$ of oxide. The current efficiency was $31 \%$. ( $\mathrm{c}$ and $d)$ Deposit with ball-like structures and potassium containing plates. Melt composition $2.7 \mathrm{~m} / \mathrm{o}$ of niobium and $2.97 \mathrm{~m} / \mathrm{o}$ of oxide. The current efficiency was $62 \%$.

whether $\mathrm{Nb}(\mathrm{IV}) \mathrm{OF}_{y}$ is present at all. Thus, it cannot be excluded that a certain amount of free oxide is present.

The precipitation of a reduced species with the oxidation state +4 would not affect the average oxidation state determined by the method applied here. With respect to solubilities, it is known from Raman experiments ${ }^{17}$ that melts containing $2.7 \mathrm{~m} / \mathrm{o}$ of $\mathrm{Nb}(\mathrm{V})$ and with oxide contents up to at least $5.4 \mathrm{~m} / \mathrm{o}$ can be handled at $650^{\circ} \mathrm{C}$ without any precipitation. In contrast to this, the solubility of $\mathrm{Nb}$ (IV) species is unfortunately not known. 
In a molten FLINAK bath used continuously for niobium deposition, the niobate ions will be expected to react to equilibrium with the niobium metal anode, no matter what the oxide content is. This is because the anode cannot be blocked completely by an oxide layer, because its surface is continuously renewed during the electrolytic dissolution of metal. Thus, the niobium species present in equilibrium will only be $\mathrm{Nb}(\mathrm{IV}) \mathrm{F}_{x}$ and eventually $\mathrm{Nb}(\mathrm{IV}) \mathrm{OF}_{y}$. There will be no $\mathrm{Nb}(\mathrm{V})$ species present, at least not for $\mathrm{O}: \mathrm{Nb}$ ratios less than one.
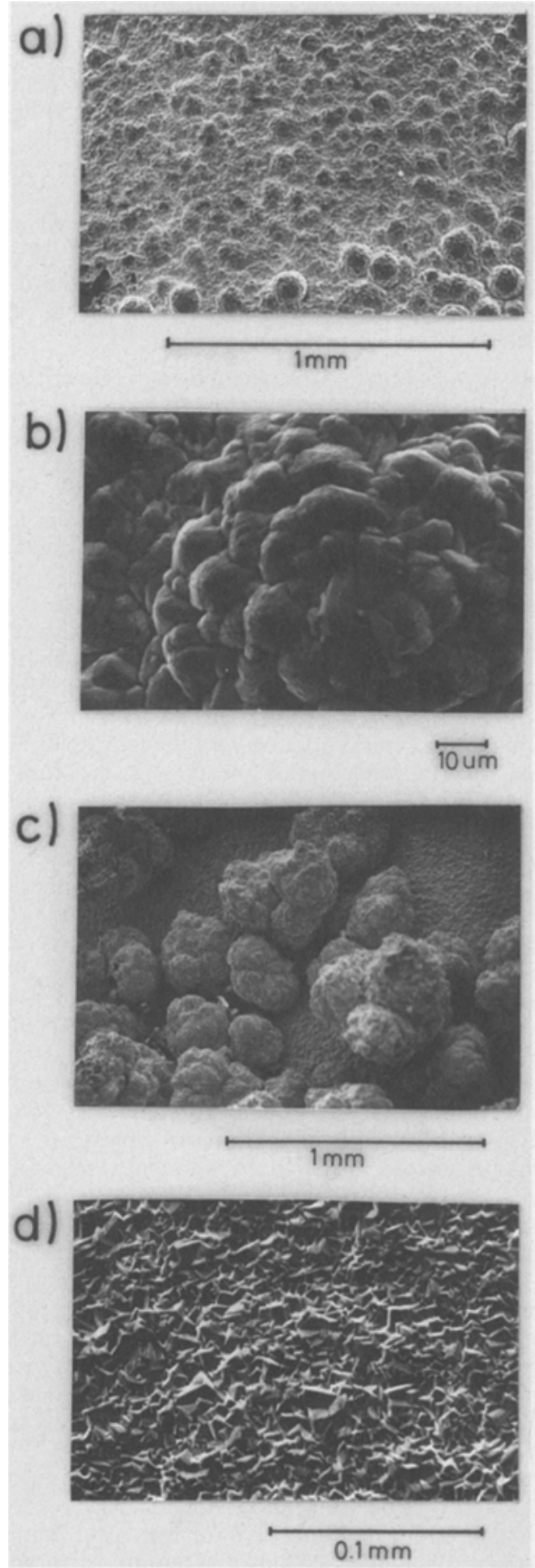

Fig. 8. SEM micrographs of surfaces of niobium deposits from melt compositions with low oxide contents. (a and b) Melt composition $3.2 \mathrm{~m} / \mathrm{o}$ of niobium and $0 \mathrm{~m} / \mathrm{o}$ of oxide. Current efficiency $22 \%$. ( $c$ and d) Melt composition $3.75 \mathrm{~m} / \mathrm{o}$ of niobium and $1.3 \mathrm{~m} / \mathrm{o}$ of oxide. Current efficiency $93 \%$.
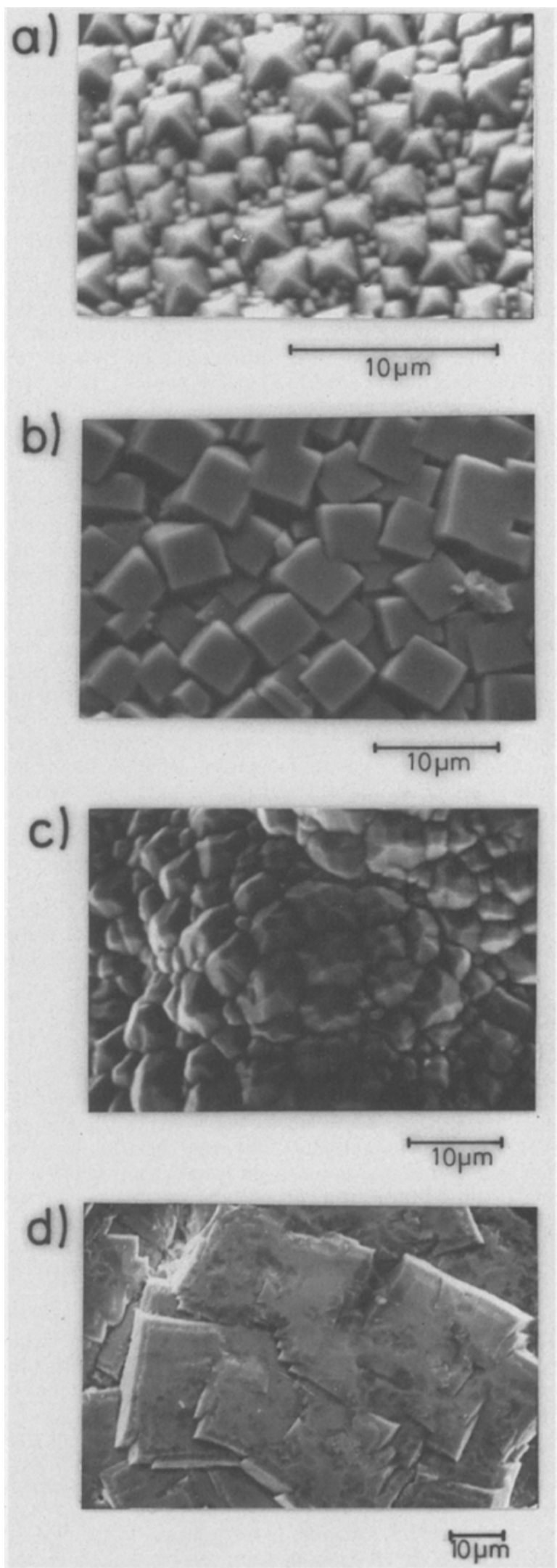

Fig. 9. Different types of niobium crystals found in deposits from melts with $\mathrm{Nb}: \mathrm{O}$ ratios close to one. The concentrations of niobium and oxide in the melts used for the deposition were, respectively, (in $\mathrm{m} / \mathrm{o})$ : (a) $(3.2,2.7$; (b) 3.2, 3.52; (c) 3.2, 3.52; (d) 3.75, 3.2.

Cyclic voltammetry studies.-Figure 4 shows a voltammogram of a $0.90 \mathrm{~m} / \mathrm{o}$ solution of $\mathrm{K}_{2} \mathrm{NbF}_{7}$ in a FLINAK melt at $700^{\circ} \mathrm{C}$ with $0.35 \mathrm{~m} / \mathrm{o} \mathrm{Na} \mathrm{O}_{2} \mathrm{O}$ added. The initial amount of oxide present in the FLINAK melt was approximately $0.15 \mathrm{~m} / \mathrm{o}$. Three electrochemical reactions are detected. The 
first one $\left(\mathrm{R}_{1} / \mathrm{O}_{1}\right)$ occurs at a positive potential $v$ s. $\mathrm{Ni} / \mathrm{Ni}^{2+}$. It has the shape of a reversible reaction involving a small number of electrons. The second one $\left(\mathrm{R}_{2} / \mathrm{O}_{2}\right)$ takes place at a negative potential. The reduction wave $R_{2}$ appeared at $-0.6 \mathrm{~V}$ and involved niobium deposition. The corresponding oxidation wave $\left(\mathrm{O}_{2}\right)$ is steep and characteristic of a stripping reaction. The third redox-reaction $\left(\mathrm{R}_{3} / \mathrm{O}_{3}\right)$ is believed to have connection with the presence of oxofluoro complexes. That the $\mathrm{R}_{2} / \mathrm{O}_{2}$ and $\mathrm{R}_{3} / \mathrm{O}_{3}$ waves correspond to each other, respectively, is clear if the potential range is varied. ${ }^{21}$ It can be seen from Fig. 5 that the reduction wave $R_{2}$ diminishes with the addition of oxide to the melt. At the same time the reduction wave $R_{3}$ seems to grow. To explain the variation of the reduction waves with the amount of oxide added we make the following assumptions: the FLINAK melt has a residual oxide content of around $0.1 \mathrm{~m} / \mathrm{o}$, and furthermore a certain smaller or larger amount of oxide, besides the added amount, is introduced into the system during each $\mathrm{Na}_{2} \mathrm{O}$ addition, as a result of experimental difficulties. On the basis of this the $\mathrm{R}_{3} / \mathrm{O}_{3}$ redox reaction (Fig. 5) can be explained as the reduction of a mono-oxofluoro complex, and the $\mathrm{R}_{4} / \mathrm{O}_{4}$ redox reaction as the reduction of the $\mathrm{NbO}_{2} \mathrm{~F}_{4}^{3-}$ complex. If the oxide to niobium molar ratio is sufficiently high, the $R_{2}$ wave will disappear completely and the $R_{3}$ and $R_{4}$ waves are the dominating reduction waves. The weak $R_{1}$ wave (Fig. 4) diminished with oxide additions and completely vanished when the oxide to niobium ratio was one. In the region between $R_{1}$ and $R_{2}$ (Fig. 4) it seems that the rate of reduction begins to accelerate. This could be due to formation of a niobium/platinum alloy on the surface of the working electrode. Preliminary $x$-ray investigations of deposits formed on platinum foil at these potentials suggest that such deposits are indeed formed.

On the basis of these observations, and on the basis of the results from the chemical reduction experiments indicating that besides the oxidation state V, IV is the only other stable oxidation state of niobium in the melt, we suggest that the $R_{1}$ and $R_{2}$ waves are due to reduction of niobium fluoro complexes according to a reduction mechanism such as

$$
\begin{gathered}
\mathrm{NbF}_{7}^{2-}+e^{-} \rightarrow \mathrm{NbF}_{x}^{(x-4)}+(7-x) \mathrm{F}^{-} \\
\mathrm{NbF}_{x}^{(x-4)^{-}}+4 e^{-} \rightarrow \mathrm{Nb}+x \mathrm{~F}^{-}
\end{gathered}
$$

This is in accordance with the reduction path proposed by Barhoun et al., ${ }^{14}$ Konstantinov et al., ${ }^{10}$ and by Zhiyu and Taxil ${ }^{11}$ for $\mathrm{K}_{2} \mathrm{NbF}_{7}$ dissolved in $\mathrm{NaCl}-\mathrm{KCl}, \mathrm{KCl}-\mathrm{KF}$, and $\mathrm{LiF}-\mathrm{NaF}$ melts, respectively. However, the $\mathrm{R}_{1} / \mathrm{O}_{1}$ wave is rather weak, and one could argue that it may be due to formation of a film. On the other hand, in voltammograms of oxide-free melts ${ }^{21}$ (i.e., where $\mathrm{NbF}_{7}^{2-}$ is the only $\mathrm{Nb}(\mathrm{V}$ ) complex present) the $R_{1} / O_{1}$ wave is much more intense and clearly due to the $\mathrm{V} \rightleftharpoons \mathrm{IV}$ reduction couple also observed by other authors..$^{10.11,14}$

In Fig. 4 oxide has been added to the melt, and furthermore the solvent contained approximately $0.15 \mathrm{~m} / \mathrm{o}$ oxide. This means that more than half of $\mathrm{Nb}(\mathrm{V})$ is present as the mono-oxofluoro complex, which shows only one reduction step, $\mathbf{R}_{3}$.

As already mentioned, the reduction mechanism proposed above is in disagreement with the results from other investigators..$^{3,6,13,15}$ In this connection it is interesting to compare the different reduction potentials which have been obtained by various investigators for $\mathrm{Nb}(\mathrm{V})$ in FLINAK melts. Such a comparison can be seen in Table I. Only potentials which have been measured against the $\mathrm{Ni}$ / $\mathrm{NiF}_{2}$ reference electrode are given in this table. It is interesting to note that the reduction potentials measured by the authors of Ref. 3, 6, and 15 all claimed to be due to reduction of fluoro complexes. It is, however, clear that most of the given reduction potentials are close to the potentials found by us for the mono-oxo- and dioxofluoro complexes. The reason for this is probably that the initial concentrations of $\mathrm{Nb}(\mathrm{V})$ in these experiments were rather small $(0.1 \mathrm{~m} / \mathrm{o}$ or less $)$. Since we know that it is very difficult to make a FLINAK melt with an oxide content of less than
$0.1 \mathrm{~m} / \mathrm{o}$ we believe that the reduction potentials given in these articles ${ }^{3,6,15}$ are due to reduction of oxofluoro rather than fluoro complexes.

The $R_{3}$ wave in Fig. 4 may result from the reduction of either a $\mathrm{Nb}(\mathrm{V})$ or a $\mathrm{Nb}$ (IV) mono-oxofluoro complex. If the latter is the case, a reduction wave corresponding to Eq. 11 would be expected to appear in the voltammograms

$$
\mathrm{Nb}(\mathrm{V}) \mathrm{OF}_{5}^{2--} \rightarrow \mathrm{Nb}(\mathrm{IV}) \mathrm{OF}_{y}+e^{-}+(5-y) \mathrm{F}^{-}
$$

Such a wave is not clearly seen, which indicates that oxofluoro complexes of $\mathrm{Nb}(\mathrm{IV})$ do not exist in major concentrations. The process observed by Senderoff and Mellors ${ }^{3}$ and by Nakagawa and Hirobayashi ${ }^{15}$ at -0.11 and $-0.2 \mathrm{~V}$, respectively, could be suggested to be the reduction of $\mathrm{Nb}$ (V)OF $\mathrm{OF}_{5}^{2-}$ to $\mathrm{Nb}$ (IV)OF $\mathrm{OF}_{y}$. This matter is presently under further investigation at our laboratory,

There is an interesting difference between our results for FLINAK melts and the electrochemical results reported by Chemla and Grinewitch ${ }^{9}$ and Konstantinov et $a .^{10}$ for mixed chloride-fluoride melts. In the latter cases the niobium oxofluoride species is reduced at a less reducing potential than $\mathrm{Nb}(\mathrm{IV}) \mathrm{F}_{x}$, i.e., when oxide is present in such melts, the oxofluoride will be the first to react. Furthermore, apparently the niobium oxofluoride could not be reduced to $\mathrm{Nb}$ (IV), and only niobium(V) oxofluoride species were present..$^{9,10}$

Plating experiments.-We decided to perform the plating experiments in such a way that the reaction between $\mathrm{Nb}(\mathrm{V})$ in the melt and the niobium anode was allowed to take place before the electrolysis was started.

No pre-electrolysis to remove metal impurities from the melt was carried out because this purification process could also remove some of the oxide added and might influence the oxidation state of niobium.

The time necessary to reach equilibrium for the reaction between $\mathrm{Nb}(\mathrm{V})$ and niobium metal was found to be approximately $1 \mathrm{~h}$ when no oxide was present. For the melt composition $2.7 \mathrm{~m} / \mathrm{o} \mathrm{Nb}(\mathrm{V})$ and $2.7 \mathrm{~m} / \mathrm{o}$ oxide, the equilibration time appeared to be in the range of 3 to $6 \mathrm{~h}$. The determination of this period could only be very inaccurate as already discussed. On the other hand, because the niobium metal present was the anode, its surface would, at least partially, be kept free from oxide as soon as the electrolysis was started. This would be expected to accelerate the chemical reduction process very much during the first part of the electrolysis period, if the state of equilibrium had not been reached already. Thus, it was decided to keep the electrodes in the melt for a period of $3 \mathrm{~h}$ before initiating the electrolysis. Due to the construction of the cell (Fig. 2), it was necessary also to keep the steel electrode dipped into the electrolyte for $3 \mathrm{~h}$ together with the niobium electrode. During this period the potential difference between the two electrodes always changed from a value around $-150 \mathrm{mV}$ to 0 . To investigate this phenomena more closely, an experiment was performed in which both a steel electrode and a niobium electrode were immersed in the melt for $3 \mathrm{~h}$. The FLINAK melt contained $2.7 \mathrm{~m} / \mathrm{o} \mathrm{K}_{2} \mathrm{NbF}_{7}$ and $1.0 \mathrm{~m} / \mathrm{o} \mathrm{Na} \mathrm{N}_{2} \mathrm{O}$. After this treatment the surface of the steel electrode was covered by a dark layer, which by EDX analysis was shown to consist of niobium and to have a thickness of only a few microns. This is in accordance with the fact that the potential difference between the two electrodes, when immersed in the melt, always approaches zero, as mentioned above. It should be noted that this is the "starting point" for our electrochemical niobium deposition.

To establish whether dissolution of iron was a problem of importance, a number of melts with different contents of niobium and oxide were analyzed for iron after being used for plating experiments. When the niobium content was $5 \mathrm{~m} / \mathrm{o}$ or below, as in the plating experiments reported in this work, the melts contained only very small amounts of $\mathrm{Fe}, 0.007$ to $0.03 \mathrm{w} / \mathrm{o}$. The weight loss caused by this dissolution of iron will give an error in the current efficiency of approximately $0.3 \%$. This is considered to be acceptable. 
On the other hand for melts with niobium contents of $8 \mathrm{~m} / \mathrm{o}$, severe corrosion of the iron electrode was observed. The Fe content in such melts reached $0.5 \mathrm{w} / \mathrm{o}$.

An overview of the results of the plating experiments is given in Fig. 6. The way of presenting the results, i.e., as average values over several plating experiments, has been chosen because of difficulties in making reproducible determinations of current efficiencies at each melt composition, partly due to variations in the current densities of the cathode. The current density was averaged for the first 75 experiments $94 \pm 18 \mathrm{~mA} / \mathrm{cm}^{2}$ (standard error). It can be seen from Fig. 6, that current efficiencies are high only for experiments within the range of the areas $B$ and $E$. Deposits of the highest quality (crystallinity, coherence) were obtained for melt compositions in areas $\mathrm{A}$ and $\mathrm{B}$ with the molar ratio $\mathrm{O}: \mathrm{Nb}$ somewhat lower than one as will be discussed below. Anyway, our data indicate that it is an advantage to have a certain amount of oxide in the melt. This is in contrast to earlier result $\mathrm{s}^{1, \tilde{0}, 7,11,15}$ where it has been assumed that the melt should not contain any oxide. It must, however, be borne in mind that the current efficiency as well as the quality of the deposits probably also is strongly affected by the current density, as observed by Zhiyu and $\mathrm{Taxi}^{11}$ for the deposition of niobium from LiF-NaF-melts. The ranges of melt composition which give certain types of deposits must therefore be expected to vary with the current density.

For melt compositions with initial $\mathrm{O} / \mathrm{Nb}(\mathrm{V})$ ratios smaller than one $[\mathrm{O} / \mathrm{Nb}(\mathrm{V})=1$ corresponds to 1.0 oxide: $1.25 \mathrm{Nb}(\mathrm{IV})]$, pure metal (analyzed by EDX) was always deposited. In this composition range $\mathrm{Nb}(\mathrm{IV}) \mathrm{F}_{x}$ and possibly $\mathrm{Nb}(\mathrm{IV}) \mathrm{OF}_{y}$ are the dominating niobium species. According to our electrochemical investigations, $\mathrm{Nb}(\mathrm{IV}) \mathrm{F}_{x}$ is reduced to metal in a four-electron step at the least reducing potential, i.e., this will be the first and most important species to be reduced. However, it is of course possible that oxidation states lower than four are formed at the anode during the electrolysis. Such species may also be involved in the deposition process. Figure 7a shows the morphology of a deposition from a melt in the composition range giving the best quality of the niobium layer (areas A or B in Fig. 6). When the molar ratio $\mathrm{O}: \mathrm{Nb}$ is approaching one, the layer is gradually changing towards a texture built up of ball-like structures as can be seen by comparison of Fig. $7 \mathrm{a}$ and $\mathrm{b}$. When the oxide to niobium ratio is higher, as in the $\mathrm{C}$ area of Fig. 6, the layer also contains plates of typically 20 atomic percent $(\mathrm{a} / \mathrm{o})$ of potassium and $80 \mathrm{a} / \mathrm{o}$ of niobium (by EDX analysis) along with the ball-like structures consisting of pure niobium (Fig. $7 \mathrm{c}$ and d). Such deposits appear black by visual inspection. When the oxide content is further increased, the total content of potassium increases and the layer becomes more porous with a poor mechanical stability as a result. The apparent current efficiency drops, since the deposited layer flakes off during removal of the solidified melt. The potassium containing phase is probably a potassium niobate. When the molar ratio $\mathrm{O} / \mathrm{Nb}$ is greater than one, the formation of potassium containing deposits is a problem in general. Potassium contents of more than $30 \mathrm{a} / \mathrm{o}$ have been found. In this composition range the niobium species present are an $\mathrm{NbO}_{2} \mathrm{~F}_{z}$ speeies and $\mathrm{Nb}(\mathrm{IV}) \mathrm{F}_{x}$, and possibly $\mathrm{Nb}(\mathrm{IV}) \mathrm{OF}_{y}$. In the first species mentioned, niobium may be present as $\mathrm{Nb}(\mathrm{V})$ or as $\mathrm{Nb}(\mathrm{TV})$. The potassium containing plates can be assumed to be either the product of the reduction of this species, at $R_{4}$ (Fig. 5), or they may be formed at $R_{3}$ (Fig. 4) by the reduction of a mono-oxofluoro complex. It is not possible on the basis of the present data to determine exactly at what potential this type of deposit is formed.

As can be seen from Fig. 6, there are considerable variations in morphology as well as in current efficiency for melt compositions within the area giving pure metal deposits. For melt compositions in the range of the D area in Fig. 6, deposits as shown in Fig. 8 b are found. Here is also a clear tendency to form ball-like structures, but in this case they are generally smaller. A characteristic feature is that the niobium metal crystals are less well defined (Fig. 8b).
In the $\mathrm{E}$ area in Fig. 6, which is the range of high niobium contents and still relatively low oxide contents, strongly dendritic deposits are formed (Fig. 8c). The metal crystals have a very characteristic appearance (Fig. $8 \mathrm{~d}$ ).

In the $A$ and $B$ areas in Fig. 6 the niobium crystals appear in at least four different shapes (Fig. 9). It is not clear exactly when they appear. There are generally several types found at different places on the same sample. Local variations in current density due to the lack of agitation may be the reason for this phenomenon.

The different types of deposits seem to be related to the presence of certain species that give the solidified melts characteristic colors after the plating experiments. It is well known that the lower valence states of niobium are strongly colored because of $\mathrm{d}-\mathrm{d}$ - transitions. Probably small amounts of such species are formed during the electrolysis. Melts giving deposits as in Fig. 7a are light yellow or yellowish green after the experiments. Ball-like formations as in Fig. 7b, c, and $d$ are observed in deposits from green melts, and small $\mathrm{O} / \mathrm{Nb}$ ratios give purple melts. Very high oxide contents ( 5 to $6 \mathrm{~m} / \mathrm{o}$ ) give blue-colored melts with a black or dark blue precipitate. This precipitate has been shown by XRD to contain no niobium metal. As there is also no niobium deposited, it can be concluded that in such cases niobium metal is not formed at all during the electrolysis.

The appearance of these colors as well as the variation in cathodic current efficiency with composition indicate that the overall mechanism of the electrolytic process is more complicated than revealed by the voltammetric investigation of the cathode processes only. It seems that there are two separated ranges of melt composition giving high current efficiencies (Fig. 6) indicating that several side reactions or reverse reactions might be competing.

\section{Acknowledgments}

Thanks are due to The Danish Council for Technical Research which has supported this work financially (under the FTU program). Further the Mads Clausens Foundation and Julie Damms Studiefond are also acknowledged for financial support. T. Østvold received financial support from Fondet for Dansk-Norsk Samarbejde during his stays at DTH.

Manuscript submitted Oct. 1, 1993; revised manuscript received Feb. 1, 1994.

\section{REFERENCES}

1. G. W. Mellors and S. Senderoff, This Journal, 112, 266 (1965).

2. G. W. Mellors and S. Senderoff, ibid., 113, 60 (1966).

3. S. Senderoff and G. W. Mellors, ibid., 113, 66 (1966).

4. S. Senderoff, Metall. Revs., 11, 97 (1966).

5. S. Senderoff and G. W. Mellors, This Journal, 114, 556 (1967).

6. P. Los and J. Josiak, B. Electrochem., 5, 829 (1989)

7. U. Cohen, This Journal, 128, 731 (1981).

8. T. Yoko and A. Bailey, in Proceedings of 1st International Symposium on Molten Salt Chemistry and Technology, p. 111 (1983)

9. M. Chemla and V. Grinevitch, Bull. Soc. Chim. France, N3, 853 (1973).

10. V. I. Konstantinov, E. G. Polyakov, and P. T. Strangrit, Electrochim. Acta, 26, 445 (1981).

11. Q. Zhiyu and P. Taxil, J. Appl. Electrochem., 15, 250 (1985).

12. M. Sakawa and T. Kuroda, Denki Kagaku, 36, 653 (1968); ibid., 37, 99 (1969); (C.A., 70, 25193y; ibid., 71, 8985m).

13. A. Khalidi, P. Taxil, B. Lafage, and A. P. Lamaze, Materials Science Forum, 73-75, 421 (1991).

14. A. Barhoun, Y. Berghoute, and F. Lantelme, J. Alloys Compd., 179, 241 (1992).

15. I. Nakagawa and Y. Hirobayashi, Nippon Kagaku Kaishi, 1063 (1982).

16. K. S. Fordyce and R. L. Baum, J. Chem. Phys., 44, 1166 (1966). 
17. J. H. von Barner, E. Christensen, N. J. Bjerrum, and B. Gilbert, Inorg. Chem., 30, 561 (1991).

18. M. Sakawa and T. Kuroda, Denki Kagaku, 36, 146 (1968); (C.A., 69, 24075d).
19. G. W. Horsby, J. Iron Steel Inst., p. 43 (1956).

20. H. W. Jenkins, G. Mamantov, and D. L. Manning, J. Electroanal.Chem., 19, $385(1968)$

21. F. Matthiesen, E. Christensen, J. H. von Barner, and N. J. Bjerrum, To be published.

\title{
Use of Underpotential Deposition of Zinc to Mitigate Hydrogen Absorption into Monel K500
}

\author{
G. Zheng," B. N. Popov, ${ }^{* *}$ and R. E. White** \\ Department of Chemical Engineering, University of South Carolina, Columbia, South Carolina 29208
}

\begin{abstract}
Polarization experiments and a potentiostatic pulse technique have been used to show that a monolayer coverage of zinc effectively inhibits the absorption of hydrogen into Monel K500. By depositing a monolayer of zinc on Monel K500, the hydrogen evolution reaction and hydrogen ingress flux rate were reduced by $60 \%$.
\end{abstract}

The practical use of high strength alloys is limited by cracking hazards created by the penetration and accumulation of hydrogen in the bulk of the alloy., The sources of hydrogen causing embrittlement have been encountered in electroplating, in pickling operations, in the processes of corrosion or rusting during storage and transportation, and in the process of cathodic protections. When weakening alloys, the hydrogen will tend to accumulate in areas of high stress, and it may reach a critical hydrogen concentration. At this point microcracking will occur and may lead to a catastrophic fracture that damages the part. ${ }^{3-5}$ Also, in the presence of absorbed hydrogen, changes occur in both the lattice structure and the chemical composition of the alloy. ${ }^{6}$

Various methods have been proposed to decrease hydrogen embrittlement. ${ }^{7-10}$ Among these methods are post-heattreatment, alloying addition, laser surface modification, and shot peening. However, when using these methods, it is difficult to reduce hydrogenation of the alloy to a level which eliminates the cracking hazards.

Drazic and Vorkapic ${ }^{12}$ established that the presence of metal ions $\left(\mathrm{Cd}^{+2}\right.$, and $\left.\mathrm{Zn}^{+2}\right)$ that are more electronegative than the cathodic potential for the hydrogen evolution reaction on iron in a $0.25 \mathrm{M} \mathrm{H}_{2} \mathrm{SO}_{4}$ solution inhibits the hydrogen evolution reaction and corrosion of iron. This effect has been explained as the underpotential deposition (UPD) of the adatoms of these metals on iron. By comparing cyclic voltammetry results with data derived from the Devanathan-Stachurski method (under identical conditions), it was shown that the underpotential adsorption of zinc, bismuth, and lead onto AISI 4340 steel and Inconel 718 reduced the amount of both atomic hydrogen adsorbed and the degree of hydrogen ingress in the substrate. ${ }^{12-16}$

The objective of this work was to estimate the effectiveness of the UPD of zinc on the reduction of the hydrogen evolution rate and on the degree of hydrogen ingress into Monel K500. A monolayer of zinc was expected to reduce the surface coverage of adsorbed hydrogen and change the kinetic parameters of the hydrogen discharge reaction, thereby inhibiting the corrosion rate and reducing the absorption of hydrogen into Monel K500.

\section{Experimental}

Tafel and linear sweep voltammetry were used to investigate the possibility of the underpotential deposition of zinc on Monel K500, and to determine the diagnostic criteria for the identification of the mechanism of hydrogen discharge in the presence and absence of underpotential deposited zinc. These techniques were also used to determine the experimental UPD conditions. A potentiostatic pulse tech-

* Electrochemical Society Student Member.

* * Electrochemical Society Active Member. nique, developed by Pound et al., ${ }^{17,18}$ was used to estimate the rate of hydrogen ingress into the alloy.

The electrochemical cell employed for the Tafel method, the linear sweep voltammetry studies, and the potentiostatic pulse technique was a conventional three-compartment design with contact between the working electrode compartment and the reference electrode via a Luggin probe. The reference electrode was a saturated calomel electrode (SCE), and the auxiliary electrode was a platinum gauze with a high surface area. The experiments were conducted using the Model 342C SoftCorr System with the EG\&G Princeton Applied Research potentiostat/galvanstat Model 273 at room temperature $\left(23 \pm 1^{\circ} \mathrm{C}\right)$. ACS Reagent chemicals were used to prepare a $1 M \mathrm{Na}_{2} \mathrm{SO}_{4}, 0.4 M$ $\mathrm{NaCl}$, and $1 \mathrm{M} \mathrm{H}_{3} \mathrm{BO}_{3}$ supporting electrolyte. Several hours before the experiments were conducted, the electrolyte was degassed by passing prepurified nitrogen through the solution. The Monel K500 electrode (geometric area of $0.5 \mathrm{~cm}^{2}$ ) was inserted into a Teflon holder so that only the flat surface was exposed. The composition of the alloy in weight percent (w/o) is: Al 2.92, C 0.16, Cu 29.99, Fe 0.64, Mn 0.72, $\mathrm{Ni} 64.96, \mathrm{~S} 0.001$, Si 0.15 , and Ti 0.46 . Prior to each run, the electrode surface was mechanically polished with 600 grade $\mathrm{SiC}$ paper followed by $0.05 \mu \mathrm{m}$ aluminum powder to mirror finish, cleaned in an ultrasonic cleaning bath, and thoroughly rinsed with deionized water.

By using the potentiostatic pulse technique, the rate of hydrogen absorption into the Monel K500 electrode and the trapping constant in the presence and absence of zinc was estimated from experimental data. The test electrode was charged at a constant cathodic potential of $E_{\mathrm{c}}=-1.0 \mathrm{~V} \mathrm{vs}$. $\mathrm{SCE}$, which gives a monolayer deposition of zinc, for a time between 1 to $30 \mathrm{~s}$. Then the potential was increased to a more positive value $E_{\mathrm{A}}$ (10 $\mathrm{mV}$ more negative than the open-circuit potential $E_{\mathrm{oc}}$ ). The cathodic/anodic current and total charge accumulation during the cathodic charge/ anodic discharge process was measured simultaneously by the potentiostat/galvanostat and a recorder. The experimental results were checked by repeating the experiment for the charging time of $1 \mathrm{~s}$ to insure that neither hydrogen saturation nor internal damage occurred during the cathodic charge process. The details of this technique are explained by Pound. ${ }^{17,18}$

\section{Results and Discussion}

Cyclic voltammetry.-Figure 1 shows the linear sweep voltammetric curves which were obtained in the absence and presence of zinc ions on Monel K500 electrodes by using an electrolyte containing $1 M \mathrm{Na}_{2} \mathrm{SO}_{4}, 0.4 M \mathrm{NaCl}$, and $1 \mathrm{MH}_{3} \mathrm{BO}_{3}(\mathrm{pH} 4)$ at sweep rate of $100 \mathrm{mV}$ as shown in Fig. 1. A decrease in hydrogen evolution was observed when the experiments were carried out in the presence of $5 \times 10^{-3}$ 